\title{
Protective effect of disodium cromoglycate on rat peritoneal mast cells
}

\author{
R OBERT MARSHALL \\ The Nuffield Department of Surgery, Radcliffe Infirmary, Oxford
}

\begin{abstract}
Disruption of mast cells was measured by incubating the peritoneal washings of a rat with the substances under test. The incubate was filtered and the histamine in the undisrupted mast cells on the filter was assayed using guinea-pig ileum. Measurements were also made on disruption of rat peritoneal mast cells in vivo.

Disodium cromoglycate (DCG) reduces the in vitro disruption of peritoneal mast cells produced by Compound $48 / 80$, human plasma, dextran, and trypsin inhibitors. Compound $48 / 80$ produced its greatest mast cell disruption at a calcium concentration of $0 \cdot 2-2 \mathrm{mM} \mathrm{CaCl} 2$. DCG was effective in reducing the mast cell disruption at all calcium concentrations. Mast cell disruption by surface active agents was also reduced by DCG.
\end{abstract}

In vivo experiments showed that DCG reduced the disruptive effect of Compound $48 / 80$ on rat mesenteric mast cells.

Calculations based on bronchial morphology show that the concentrations of DCG used in these experiments may be attained therapeutically in the bronchial mucosa of man.

Disodium cromoglycate (DCG) has been found to be effective in the treatment of asthma and it has been suggested that DCG acts at some point between the union of reagin antibody with antigen and the subsequent disruption of the mast cell (Cox, 1967; Goose and Blair, 1969). This suggestion was based on the ability of DCG to inhibit the passive cutaneous anaphylactic reaction in rats, to reduce antigen-induced bronchoconstriction in marmosets, and to prevent release of spasmogens when antigen acts on sensitized lung tissue in vitro. On the other hand, DCG failed to affect skin lesions induced by Compound $48 / 80$ and it therefore appeared to have no direct protective effect on the mast cell.

This paper reports observations on the influence of DCG upon the action of various substances which cause disruption of rat peritoneal mast cells either in vitro or in vivo.

\section{METHODS}

MAST CELL DISRUPTION in vitro The method used to measure mast cell disruption follows closely that described by Lagunoff and Benditt (1960). The principle of the method is that rat peritoneal mast cells, after incubation with a possible disrupting agent, are filtered through a membrane which holds back the intact mast cells (and possibly granules) but allows non-granular substances liberated from the mast cells to pass through. The histamine (and other active sub-o stances) is liberated from the mast cells retained on 3 the filter by freezing first and thawing and it is then assayed on guinea-pig ileum.

The suspension of rat peritoneal mast cells was prepared as follows. A rat was anaesthetized with ethero and bled by cutting across the heart and thorax with scissors. Twenty millilitres of low-calcium tyrode solu- $-\frac{x}{-}$ tion (Dalgleish, Toh, and Work, 1953), to which 103 $\mu \mathrm{g} / \mathrm{ml}$ of heparin was added, was introduced into the peritoneal cavity through a small incision and the ab-윽 dominal wall was massaged for about one minute. $₹$ The peritoneal cavity was then opened widely by a음 midline incision and the fluid was removed using a plastic pipette. This suspension, in which mast cellso constituted about $4 \%$ of the total cells, was used without further purification or standardization of the mast cell content. The solutions, whose mast cell dis- $N$ rupting effect was to be tested, were pipetted, usually in $0.6-\mathrm{ml}$ volumes, into $90 \times 12 \mathrm{~mm}$ plastic tubes, and $0.7 \mathrm{ml}$ of mast cell suspension was added from aס syringe delivering a constant volume. The contents ofe one tube, in which the standard volume of mast cell $\frac{\Gamma}{\Phi}$ suspension had been added to tyrode solution, were mixed and filtered immediately. This tube is designa- $\square$ ted 'initial' in the graphs shown below and represents 0 the total histamine content of the mast cells. The $\overrightarrow{\mathbb{D}}$ other tubes were capped and incubated at $37^{\circ} \mathrm{C}$ for $\frac{\rho}{\bar{D}}$ one hour before filtration. The suspensions were fil- $\stackrel{D}{\varrho}$ tered through $25 \mathrm{~mm}$ diameter Millipore filters, $0.8 \mu$ pore diameter (Type AAWP02500) supported in $\Omega$ 
'Swinnex' filter holders. The filters were washed through with two 2-ml quantities of saline and the filter discs were removed from the holders, folded, and placed in $2 \mathrm{ml}$ of saline in a bijou bottle which was then frozen. The bottles were thawed just before assay of the histamine content on guinea-pig ileum in Kreb's solution at $37^{\circ} \mathrm{C}$ (Pharmacology Department Staff, University of Edinburgh, 1970). The results are expressed as $\mathrm{ng}$ histamine/ml of the saline solution, although it is realized that serotonin and other substances liberated from the mast cells may be increasing the contraction of the guinea-pig ileum. In Figs 1 and 4 the histamine released from the undisrupted mast cells is expressed as a percentage of the histamine released from an equal volume of cell suspension before treatment with a disrupting agent.

An advantage of the filter disc method is that, for the most part, the substances used to induce or prevent mast cell disruption are removed before assay of histamine on the guinea-pig ileum. As an additional precaution the effect of the substances used was tested by adding them to the organ bath in the concentrations used for mast cell disruption. In no case did the substances cause contraction of the ileum or alter the response to a standard dose of histamine given subsequently.

Most of the experiments were carried out using unbuffered tyrode solution, the $\mathrm{pH}$ of which at $37^{\circ} \mathrm{C}$ was approximately $7 \cdot 5$. Although Högberg and Uvnäs (1960) reported maximum mast cell disruption at

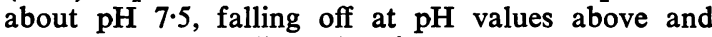
below this level, disruption in our experiments has been maximum at a $\mathrm{pH}$ of about 7.0 and variation of disruption with change of $\mathrm{pH}$ was much less than that found by Högberg and Uvnäs. DCG dissolves in normal saline with very little effect on the $\mathrm{pH}$ of the saline, and the pH of tubes put up in duplicate with those used for histamine assay showed no significant difference between the DCG tubes and the controls.

MAST CELL DISRUPTION in vivo White rats of about $300 \mathrm{~g}$ were anaesthetized with ether ; $2.5 \mathrm{ml}$ of tyrode solution (for the tyrode controls) or $2.5 \mathrm{ml}$ of tyrode solution containing $1 \mathrm{mg}$ of DCG were injected intraperitoneally. One minute later, while the rat was still anaesthetized, $2.5 \mathrm{ml}$ of tyrode solution or $2.5 \mathrm{ml}$ of tyrode containing $1 \mu \mathrm{g} / \mathrm{ml}$ of Compound $48 / 80$ was injected intraperitoneally. The animals were allowed to recover from the anaesthesia and 5 minutes later were re-anaesthetized with ether and killed by cutting across the chest. The abdomen was opened and, by picking up the gut with forceps so that the mesentery was not handled, 'windows' of mesentery were stretched across 'embroidery-rings' of $12 \mathrm{~mm}$ diameter made from the tops of disposable plastic tubes. Three 'windows' were prepared from each rat. The mesenteries were fixed in $10 \%$ formol saline, stained with $0.1 \%$ acidic aqueous toluidine blue for one minute, rinsed with water, and examined under the microscope. One hundred mast cells were counted in each ring and the number of disrupted cells was recorded. In most of the cells recorded as disrupted the damage was marked with most of the granules widely dispersed. Cells with only a few granules outside the cell boundary, but which otherwise appeared intact, were recorded as not disrupted.

The substances used to produce mast cell disruption were (1) Compound 48/80 (Wellcome Research Laboratories). This is a condensation product of $p$ methoxyphenethylmethylamine with formalin and is an effective mast cell disrupting agent in many species ; (2) dextran, as Rheomacrodex (Pharmacia) of molecular weight 40,000 in normal saline; (3) aprotinin (Trasylol, FBA Pharmaceuticals Ltd.) in ampoules of 5,000 units per mil. ; (4) ovomucoid from egg white (Sigma Chemicals Co. Type 11-0); (5) plasmin, grade B (Kabi Pharmaceuticals Ltd.); (6) urokinase (Leo Laboratories Ltd.) as the partially purified reference standard containing 2,400 Ploug units per ampoule.

\section{RESULTS}

The influence of DCG was studied on the mast cell disrupting effect of the following substances:

(a) COMPOUND 48/80 An experiment was carried out on the effect of $0.25 \mu \mathrm{g}$ of Compound $48 / 80$ on a single preparation of mast cells with six control tubes and six tubes containing $1 \mathrm{mg}$ DCG. The mean mast cell disruption in the control tubes was $92 \%$ (S.D. 1.4) and in the tubes with DCG $82 \%$ (S.D. 2.7). The difference was significant $(P<0.001)$. A concentration of $0.25 \mathrm{mg}$ $\mathrm{DCG} / \mathrm{ml}$ in the reaction tube usually reduced the mast cell disruption from the control figure of $80-95 \%$ (i.e., $5-20 \%$ remain undisrupted) to about $60-80 \%$ (i.e., $20-40 \%$ of the cells remain undisrupted).

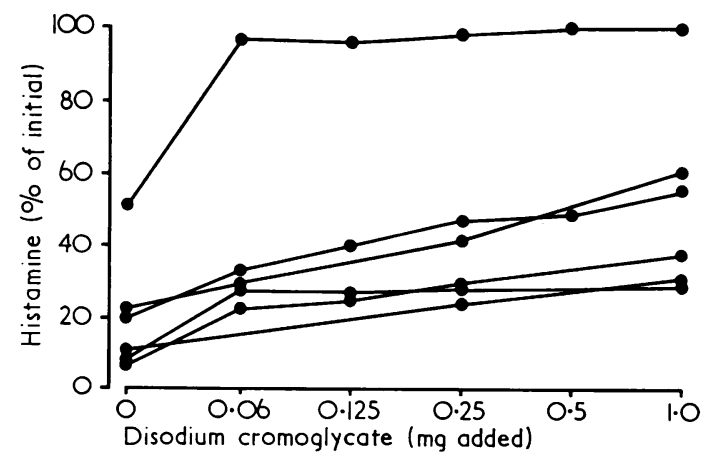

FIG. 1. Effect of varying concentrations of DCG on mast cell disruption by Compound 48/80. Ordinate, histamine in the remaining mast cells expressed as a percentage of the initial histamine content, i.e., the percentage of mast cells not disrupted. The mast cells of one rat were unusually resistant to disruption. 
Figure 1 shows the results of six experiments using the mast cells from six different rats. Analysis of the results at concentrations of 1.0 $\mathrm{mg}$ and $0.25 \mathrm{mg} \mathrm{DCG} / \mathrm{ml}$ shows a significant reduction of mast cell disruption as compared with the controls. The mast cell disruption in the control tubes was $80 \cdot 2 \%$ mean (S.D. $15 \cdot 1$ ), whereas with $10 \mathrm{mg}$ DCG the disruption was $47.7 \%$ mean (S.D. 24.4) and with 0.25 mg DCG the disruption was $55.5 \%$ mean (S.D. 25.2). In Fig. 1, these results are expressed as histamine (\% of initial) remaining in the undisrupted mast cells and thus appear as $19.8 \%, 52.3 \%$, and $44.5 \%$ respectively. The reduction in mast cell disruption as compared with the controls was significant both for $1.0 \mathrm{mg}$ DCG $(P<0.001)$ and for $0.25 \mathrm{mg}$ DCG $(0.01>$ $P>0001$ ). Also the effect of $1.0 \mathrm{mg}$ DCG was significantly different from that of $0.25 \mathrm{mg}(0.05>$ $P>0$ 02).

The standard tyrode solution used in these experiments contained $30 \mathrm{mg} / 1$ of calcium chloride $(0.27 \mathrm{mM} \mathrm{CaCl})$. Högberg and Uvnäs (1960) reported that calcium ions are necessary for mast cell disruption by Compound 48/80 and found that although about $28 \%$ disruption was produced in $0.1 \mathrm{mM} \mathrm{CaCl}_{2}$, the maximum effect was produced by concentrations of $1.0 \mathrm{mM}$ and

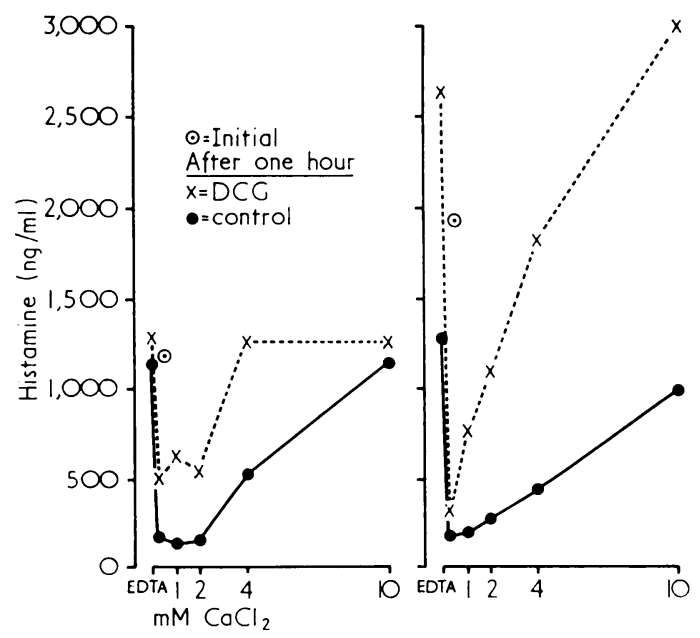

FIG. 2. Effect of varying calcium concentrations on mast cell disruption bv Compound 48/80. Results of two experiments. Ordinate, histamine content of saline after disruption of mast cells on Millipore filter (i.e., from cells not disrupted during incubation). Abscissa, $\mathrm{mMCaCl}$ in the tubes during incubation. 'Initial' shows the histamine content of an equal volume of mast cell suspension before disruption; after incubation for 1 hour at $37^{\circ} \mathrm{C}$ with $D C G$ $1 \mathrm{mg}(\times)$; and tyrode only (O). greater. Mast cell disruption, investigated by the $\stackrel{\frac{O}{0}}{\frac{D}{0}}$ method used in this study, showed a different $\frac{C}{O}$ effect of calcium concentration. The maximum $\frac{\bar{\omega}}{\mathrm{s}}$ disruption was at low calcium levels although in $\vec{\Phi}$ the presence of EDTA $(2 \mathrm{mg} / \mathrm{ml})$ mast ceil dis- $\varrho$ ruption was reduced (Fig. 2). DCG reduced the क mast cell disruption at all levels of calcium $\overrightarrow{0}$ tested.

(b) Human Plasma Human plasma in volumes of $\vec{\omega}$ $0.6 \mathrm{ml}$ added to the test system causes more dis- $\vec{x}$ ruption of mast cells than that produced by tyrode solution. The agent responsible for this is not. known and is still under investigation. The effect $\vec{\omega}$ of DCG on mast cell disruption by plasma or ${ }^{\infty}$ serum from the same subject was variable. At best, $\stackrel{5}{3}$ DCG considerably reduced mast cell disruption by $\vec{c}$ plasma and also reduced the disruption by tyrode solution, but in some cases DCG appeared to have little effect. In experiments on mast cell preparations from seven different rats the mean mast cell $\vec{\varphi}$ disruption produced by plasma was $63.9 \%$ (S.D. Nै 23.3 ), with the addition of $1 \mathrm{mg}$ DCG $34.7 \%$ (S.D. 6.2) and with $0.25 \mathrm{mg}$ DCG $44.0 \%$ (S.D. 7.5). The reduction in mast cell disruption with DCG as compared with the controls was significant for both $1 \mathrm{mg} \quad(0.01>\mathrm{P}>0005)$ and $0.25 \quad \mathrm{mg} \stackrel{\square}{\varnothing}$ (0 05 $>\mathrm{P}>0$ 025) additions.

(c) DEXTRAN Dextran causes disruption of rato $\overrightarrow{\overline{0}}$ mast cells in vivo (Jasmin, 1956; Keller, 1957) but Lagunoff and Benditt (1960), using $1 \mathrm{mg} / \mathrm{ml}$ of dextran, were unable to demonstrate disruption of rat peritoneal mast cells isolated on Millipore filters. Goth (1968) reported that glucose interferedo with the action of dextran on mast cells and this:may have been the reason for the negative results 3 . obtained by Lagunoff and Benditt. Dextran ino glucose-free tyrode was used in five experiments 3 and $10 \mathrm{mg}$ in the reaction tube produced a mean mast cell disruption of $39 \%$ (S.D. 10.6) and this was reduced significantly to $22 \%$ (S.D. 11.9 ) $(005>P>0025)$ by the addition of $1 \mathrm{mg}$ DCG.

(d) PROTEOLYTIC-ENZYME INHIBITORS Trypsin in = hibitors such as aprotinin (Trasylol) or ovomucoido produce mast cell disruption and the effect isw reduced by DCG. In 10 experiments 500 units of aprotinin increased mast cell disruption from ao mean of $14.3 \%$ (S.D. 13.1) in the control tubesD to a mean of $44.3 \%$ (S.D. 16.8) $(0005>\mathrm{P}>0.001) \stackrel{\text { ? }}{+}$ The addition of $1 \mathrm{mg}$ DCG produced a significanto reduction of mast cell disruption to a mean of $12.8 \%$ (S.D. 10.4) $(\mathrm{P}<0.001)$.

In six experiments, mast cell disruption in the control tubes (mean $13.5 \%$, S.D. 11.7) was increased by $1 \mathrm{mg}$ of ovomucoid (mean $28.9 \%$, S.D 


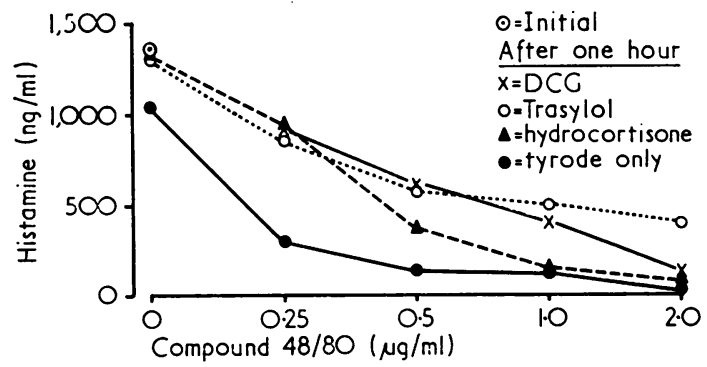

FIG. 3. Effect of DCG, aprotinin (Trasylol), and hydrocortisone, comparea with a tyrode control, on mast cell disruption by varying concentrations of Compound 48/80. Ordinate as in Fig. 2.

15.4) but was reduced when $1 \mathrm{mg}$ DCG was added (mean $8.7 \%$, S.D. 12.6). The increase in mast cell disruption with ovomucoid $(001>P>0005)$ and the reduction when DCG was added $(0.005>P>$ $0.001)$ are both significant.

It is interesting that aprotonin and, to a much lesser extent, ovomucoid have an effect similar to that of DCG on mast cell disruption by Compound 48/80 (Fig. 3) but DCG in concentrations similar to those used on mast cells had no inhibiting effect on trypsin when tested on fibrin plates. Neither did DCG reduce the trypsin-inhibiting effect of ovomucoid or aprotinin when tested on fibrin plates.

(e) COMPARISON OF DCG WITH HYDROCORTISONE Hydrocortisone has the property of stabilizing cell membranes; $1 \mathrm{mg}$ of hydrocortisone (as the sodium succinate) added to the reaction tubes had an effect which was often comparable to that of 1 $\mathrm{mg}$ of DCG (Fig. 3).

( $f$ ) THROMBOLYTIC ENZYMES The thrombolytic enzymes tested were plasmin and urokinase, the latter in the form of the incompletely purified reference standard. Urokinase produced mast cell disruption when 200, 400, and 1,000 Ploug units were added to the reaction tubes. DCG reduced the mast cell disruption by over $50 \%$ in each case but the results were too few for statistical analysis. The results with plasmin were inconclusive.

(g) SURFACE-ACTIVE AGENTS The effect of DCG was measured on mast cell disruption by both Tween 20 and Sterox SE. The effect of both surface-active agents varied on different preparations of mast cells and the results with Sterox SE were so variable as to be unsatisfactory for measuring the effect of DCG. The effect of DCG in reducing mast cell disruption in three experiments with varying concentrations of Tween 20 are shown in

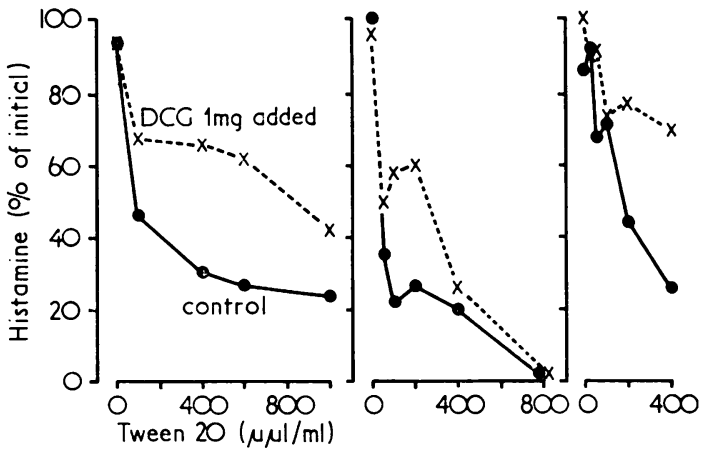

FIG. 4. Effect of DCG on mast cell disruption by Tween 20. Results of three experiments. Ordinate, histamine in the remaining mast cells expressed as a percentage of the initial histamine content.

Fig. 4. In another experiment, six pairs of tubes were set up with a concentration of Tween 20 of $400 \mu \mu \mathrm{l} / \mathrm{ml}$, and $1 \mathrm{mg}$ of DCG was added to one tube of each pair. The mast cell disruption in the control tubes was $46 \%$ (S.D. 1.11) and in the tubes containing $1 \mathrm{mg}$ DCG $8 \%$ (S.D. 3.8). The reduction in mast cell disruption produced by DCG was significant $(\mathrm{P}<0$ 001).

(h) COMPARISON OF EFFECT OF DCG AND OF DCG/LACTOSE COMBINATIONS Some sugars are able to prevent histamine release from rat peritoneal mast cells by dextran although they have very little effect on disruption by Compound 48/80 (Goth, 1959). DCG for clinical use in the Spinhaler (Fisons Pharmaceuticals Ltd.) is combined with an equal weight of lactose. In view of the possible effect of lactose on mast cell disruption a comparison was made of the effect of lactose, DCG, and the DCG/lactose combination. Figure 5 shows that lactose by itself has no effect on mast cell disruption by Compound 48/80 and in combination with DCG there was no difference from the action of DCG alone.

EFFECT OF DCG ON D'SRUPTION OF RAT PERITONEAL MAST CELLS BY COMPOUND $48 / 80$ in vivo The counts of disrupted mesenteric mast cells with Compound 48/80 and the effect of the previous addition of DCG are shown in the Table. The DCG produced a significant reduction in mast cell disruption $(P<0001)$.

\section{D:SCUSSION}

In the test system used in these experiments DCG protected mast cells from disruption not only by Compound $48 / 80$ but also by dextran, trypsininhibitors, and surface-active agents. It also 


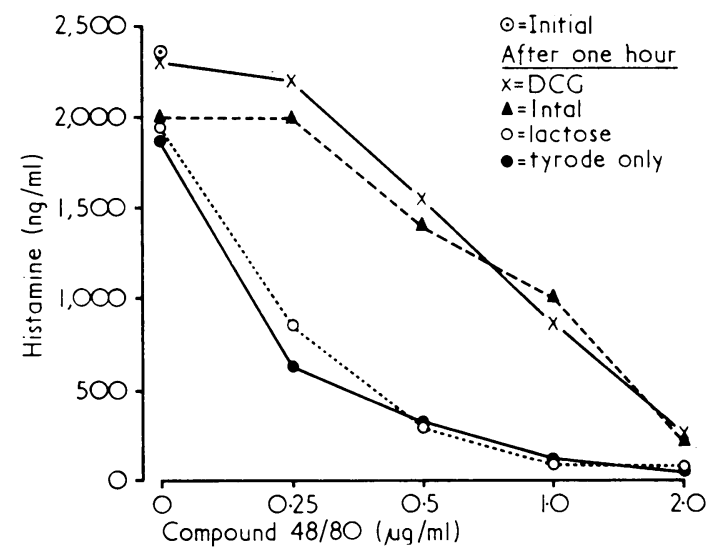

FIG. 5. Effect of DCG/lactose combination (Intal) and of DCG and lactose separately, as compared with a tyrode control, on mast cell disruption by varying concentrations of Compound 48/80. Ordinate as in Fig. 2.

T A B L E

EFFECT OF DCG ON DISRUPTION OF RAT MESENTERIC MAST CELLS BY COMPOUND 48/80 IN VIVO

\begin{tabular}{|c|c|c|c|c|}
\hline & $\begin{array}{l}\text { No. of } \\
\text { Rats }\end{array}$ & $\begin{array}{c}\text { No. of } \\
\text { 'Rings' } \\
\text { Examined }\end{array}$ & $\begin{array}{c}\% \text { Mast } \\
\text { Cell } \\
\text { Disruption } \\
\text { (mean) }\end{array}$ & S.D. \\
\hline $\begin{array}{l}\text { Control tyrode } \\
\text { Tyrode }+\end{array}$ & $\begin{array}{l}3 \\
4\end{array}$ & $\begin{array}{r}9 \\
12\end{array}$ & $\begin{array}{r}8 \cdot 3 \\
69 \cdot 8\end{array}$ & $\begin{array}{r}7 \cdot 1 \\
28.5\end{array}$ \\
\hline $\begin{array}{l}\text { DCG+ } \\
\text { Compound 48/80 }\end{array}$ & 5 & 15 & $17 \cdot 3$ & $23 \cdot 1$ \\
\hline
\end{tabular}

reduced the spontaneous disruption of mast cells which occurred on incubation for one hour in tyrode solution.

Although earlier experiments (Cox, 1967; Goose and Blair, 1969) indicated that DCG had a specific action in blocking the effect of antigenantibody complex on the mast cell, later experiments by Orr and Cox (1969) have shown that DCG inhibits disruption of rat mast cells by phospholipase A. Orr suggested that there is a common pathway in mast cell disruption by phospholipase $\mathrm{A}$ and the antigen-antibody complex, but Keller (1966) has put forward reasons for believing that phospholipase is not involved in mast cell disruption by immune reactions.

I have investigated the effect of DCG on mast cell disruption in vitro by both phospholipase A and $\alpha$-chymotrypsin which Keller (1966, p. 105) has suggested may be involved in mast cell disruption by antigen/antibody reactions. Although earlier workers (Högberg and Uvnäs, 1958) had demonstrated mast cell disruption by phospholipase-A from bee venom, Keller (1964) showed that purer $\frac{0}{0}$ phospholipase-A had no action unless a heat-labile $\frac{}{0}$ serum factor was present. This finding has been $\bar{\omega}$ confirmed in this laboratory in so far as large $\vec{\nabla}$ amounts of phospholipase-A $(20-40 \mu \mathrm{g})$ (Boeh- 응 ringer, Mannheim) in the test system produce only $\&$ an additional $15 \%$ mast cell disruption as com- $\overrightarrow{0}$ pared with a tyrode control. This additional mast cell disruption, however, is reduced by DCG. The $\vec{\omega}$ presence of human serum in the test system usually produces $80-100 \%$ mast cell disruption with $2 \mu \mathrm{g} \times$ of phospholipase-A. This disruption is usually $\mathbb{V}$ reduced by DCG but the action of DCG is vari- $-\overrightarrow{.}$ able and in some instances increased mast cell $\omega_{\infty}^{\omega}$ disruption is produced.

In relatively high concentrations $(50-100 \mu \mathrm{g} / \mathrm{ml}) \vec{\sim}$ $\alpha$-chymotrypsin caused mast cell disruption in tyrode solution and the effect was inhibited by DCG but the addition of either fresh or heatinactivated $\left(60^{\circ} \mathrm{C}\right)$ human serum completely prevented mast cell disruption by $\alpha$-chymotrypsin, a finding contrary to that of Keller $(1966$, p. 34).

The mast cell counts on rat mesentery show that DCG has a protective effect against the disruptive action of Compound 48/80 in vivo, when the DCG is brought into direct contact with the mast cells in fairly high concentration. The concentra- $\stackrel{\perp}{\varnothing}$ tion of DCG used in the tests reported here are $\overrightarrow{\vec{O}}$ much greater than those reported in the blood of 3 man. Maximum blood levels after inhalation of $\supset$ DCG are reached in about 10 minutes and after inhalation of three $20-\mathrm{mg}$ capsules the blood contains $0.25 \mu \mathrm{g} / \mathrm{ml}$ (Fisons Pharmaceuticals Limited, 으 1968). Plasma of blood taken from a subject $10 \tilde{x}$ minutes after inhalation of five $20-\mathrm{mg}$ capsules of DCG did not cause less mast cell disruption than control plasma taken before the inhalation.

Bronchial tissue levels of DCG after inhalation of the drug may be much higher than the blood 음 levels. The surface area of the bronchial tree down $D$ to the level of airways with a diameter of about $1 \mathrm{~mm}$ is approximately $1,000 \mathrm{~cm}^{2}$ when calculated $\mathrm{N}$ from the measurements of either Weibel (1963) or Horsfield and Cumming (1968). Many of the 0 mast cells in the wall of the smaller bronchi lie $\omega$ within $0.1 \mathrm{~mm}$ of the lumen and thus the volume of tissue in the lungs in which DCG must beco distributed in order to be effective is only about $\bar{\varnothing}$ $10 \mathrm{ml}$. If one capsule of $20 \mathrm{mg}$ of DCG were to $\stackrel{?}{+}$ be completely absorbed into this volume of tissue 7 the tissue concentration would be $2 \mathrm{mg} / \mathrm{ml}$. Thus $\frac{0}{\mathbb{D}}$

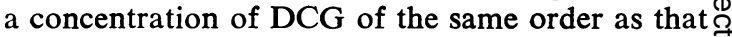
used in these experiments $(0.7 \mathrm{mg} / \mathrm{ml}$ after dilu- $\stackrel{\mathbb{Q}}{\circ}$ tion with the mast cell suspension) may be attain- -0 able in clinical use. 
Although DCG presumably acts on submucosal mast cells in the bronchi, it is interesting that Compound 48/80 has no bronchoconstricting effect (as judged by the 1 second forced expiratory volume) when inhaled. Compound $48 / 80$, given intravenously in man in doses up to $30 \mu \mathrm{g} / \mathrm{kg}$, has been found to produce cutaneous changes suggestive of histamine release (Fanciullacci and Franchi, 1964) and 35-60 $\mu \mathrm{g} / \mathrm{kg}$ produced an apparent increase in the proportion of degranulated mast cells in the bronchial mucosa (Salvato, 1962). However, the inhalation of an aerosol of $3 \%$ Compound $48 / 80$ for 40 breaths had no effect on the forced expiratory volume and neither did the inhalation of $20 \mathrm{mg}$ of Compound 48/80, diluted with powdered lactose, from a Spinhaler.

I wish to thank Fisons Pharmaceuticals Ltd. for the gift of disodium cromoglycate and FBA Pharmaceuticals Ltd. for the gift of Trasylol. The work was supported, in part, by a grant from the Research Committee of the Board of Governors of the United Oxford Hospitals.

\section{REFERENCES}

Cox, J. S. G. (1967). Disodium cromoglycate (FPL 670) (Intal): a specific inhibitor of reaginic antibody-antigen mechanisms. Nature (Lond.), 216, 1328.

Dalgliesh, C. E., Toh, C. C., and Work, T. S. (1953). Fractionation of the smooth muscle stimulants present in extracts of gastro-intestinal tract. Identification of 5-hydroxytryptamine and its distinction from substance $P$. J. Physiol. (London.), 120, 298.

Fanciullacci, M., and Franchi, G. (1964). Il liberatore di istamina 48/80 come test della funzione mastocitaria. Studio comparativo tra le varie età. G. Geront., 12, 1529.

Fisons Pharmaceuticals Limited (1968). Research Reports.
Goose, J., and Blair, A. M. J. N. (1969). Passive cutaneous anaphylaxis in the rat, induced with two hemologous reagin-like antibodies and its specific inhibition with disodium cromoglycate. Immunology, 16, 749.

Goth, A. (1959). Inhibition of anaphylactoid edema in the rat by 2-desoxyglucose. Amer. J. Physiol., 197, 1056.

- (1968). Interaction of carbohydrates and anti-inflammatory drugs with mast cells in the rat. In Chemical Biology of Inflammation, edited by B. K. Forscher, pp. 309-314. Pergamon, Oxford.

Högberg, B., and Uvnäs, B. (1958). Inhibitory action of allicin on degranulation of mast cells produced by Compound 48/80, histamine liberator from Ascaris, lecithinase A, and antigen. Acta physiol. scand., 44, 157. - (1960). Further observations on the disruption of rat mesentery mast cells caused by compound $48 / 80$, antigen-antibody reaction, lecithinase $\mathbf{A}$ and decylamine. Acta physiol. scand., 48, 133.

Horsfield, K., and Cumming, G. (1968). Morphology of the bronchial tree in man. J. appl. Physiol., 24, 373.

Jasmin, G. (1956). Étude de l'inflammation anaphylactoide. Rev. canad. Biol., 15, 107.

Keller, R. (1957). Tissue mast cells in anaphylactic shock and anaphylactoid reactions. Int. Arch. Allergy, 11, 328.

- (1964). Voraussetzungen für das Zustandekommen eines zytolysierenden Effektes durch Phosphatidase A. Helv. physiol. pharmacol. Acta, 22, C76.

- (1966). Tissue Mast Cells in Immune Reactions. Monographs in Allergy, vol. 2. American Elsevier Publishing Company, New York.

Lagunoff, D., and Benditt, E. P. (1960). Mast cell degranulation and histamine release observed in a new in vitro system. J. exp. Med., 112, 571.

Orr, T. S., and Cox, J. S. G. (1969). Disodium cromoglycate, an inhibitor of mast cell degranulation and histamine release induced by phospholipase A. Nature (Lond.), 223, 197.

Pharmacology Department Staff, University of Edinburgh (1970). Pharmacological Experiments on Isolated Preparations, 2nd ed., p. 62. Livingstone, Edinburgh.

Salvato, G. (1962). Asthma and mast cells of bronchial connective tissue. Experientia (Basel), 18, 330.

Weibel, E. R. (1963). Morphometry of the Human Lung, p. 139. Springer, Berlin. 